ORIGINAL ARTICLE

\title{
Two new species of rust fungi (Pucciniales) from the Brazilian Amazon: Aecidium margaritariae on Margaritaria and Uromyces amapaensis on Jatropha
}

\author{
Patrícia Maria Piovezan OLIVEIRA ${ }^{1}$, Helen Maria Pontes SOTÃO ${ }^{2 *} \odot$, Gabriely Serrão FREIRE², \\ Josiane Santana MONTEIRO² \\ Universidade Federal Rural da Amazônia, Programa de Pós-Graduação em Ciências Biológicas, Av. Presidente Tancredo Neves 2501, 66077-830 Belém, PA, Brazil \\ 2 Museu Paraense Emílio Goeldi, Coordenação de Botânica, Av. Perimetral 1901, Caixa Postal 399, 66077-830 Belém, PA, Brazil \\ * Corresponding author: helen@museu-goeldi.br; (D) https://orcid.org/0000-0002-1717-9532
}

\begin{abstract}
Two new species of Pucciniales fungi on plants of the Fabid clade are described from samples deposited in the herbarium of Museu Paraense Emilio Goeldi, collected in the state of Amapá, in the Brazilian Amazon. They are Aecidium margaritariae found on Margaritaria nobilis (Phyllanthaceae), and Uromyces amapaensis on Jatropha gossypiifolia (Euphorbiaceae). The microstructures of the specimens were analyzed using optical and scanning electron microscopy. Aecidium margaritariae is characterized by the presence of globose, subglobose to slightly ellipsoid aeciospores with warty walls and smooth areas usually in the basal portion. Uromyces amapaensis is distinguished by the presence of uredinia with paraphyses which are thickened and rounded at the tip, and pedicellate and smooth teliospores. Descriptions, illustrations, and taxonomic comments are presented for each species.
\end{abstract}

KEYWORDS: Basidiomycota, Brazil, Euphorbiaceae, Phyllanthaceae, Pucciniomycetes

\section{Duas novas espécies de ferrugens (Pucciniales) da Amazônia brasileira: Aecidium margaritariae sobre Margaritaria e Uromyces amapaensis sobre Jatropha}

\section{RESUMO}

Duas novas espécies de fungos Pucciniales sobre plantas do clado das fabídeas são descritas a partir de amostras depositadas no herbário do Museu Paraense Emílio Goeldi, coletadas no estado do Amapá, na Amazonia Brasileira. Aecidium margaritariae ocorrendo sobre Margaritaria nobilis (Phyllanthaceae) e Uromyces amapaensis sobre Jatropha gossypiifolia (Euphorbiaceae). As microestruturas dos espécimes foram analisadas em microscópio óptico e em microscopia eletrônica de varredura. Aecidium margaritariae se caracteriza por apresentar eciósporos globosos, subglobosos a levemente elipsoides, parede verrugosa com áreas lisas geralmente na extremidade basal. Uromyces amapaensis se diferencia por apresentar uredínios com paráfises engrossadas e arredondadas no ápice e teliósporos pedicelados, lisos. São apresentadas descriçôes, ilustraçôes e comentários taxonômicos para cada espécie.

PALAVRAS-CHAVE: Basidiomycota, Brasil, Euphorbiaceae, Phyllanthaceae, Pucciniomycetes

\section{INTRODUCTION}

In the fungi order Pucciniales, a very specific relationship between the parasitic fungus species and its host plant is observed. This specificity is a peculiar feature that favors the classic taxonomy of this group of fungi that cause rust in plants. It is used as an aid in the identification of the species, complementing morphological and molecular studies of the different stages of their complex life cycles (Cummins and
Hiratsuka 2003; Aparecido and Passador 2009, 2014; Aime et al. 2006, 2018).

About 3,000 species of fungi are reported for the Brazilian Amazon, including those of the order Pucciniales (Basidiomycota), represented by 199 known species causing rust on plants, of which 55 occur in the northern Brazilian state of Amapá (França et al. 2010; Carmo et al. 2016; Carvalho et al. 2018; Furtado et al. 2018; Flora do Brasil 2020). According 
to estimates, the Brazilian Amazon harbors about 50,000 botanical species (Cardoso et al. 2017), which suggests that many rust species likely remain undiscovered in this biome.

A taxonomic revision of Pucciniales specimens collected on Fabids and deposited in the herbarium of Museu Paraense Emílio Goeldi (Pará, Brazil) revealed the presence of two undescribed species. Here we describe the two new species of Pucciniales, which were found growing on the host species Jatropha gossypiifolia and Margaritaria nobilis, for the Brazilian Amazon in Amapá state.

\section{MATERIAL AND METHODS}

The Pucciniales specimens analyzed in this study were collected in the state of Amapá (Brazil) and were deposited in the João Murça Pires Herbarium (MG) of Museu Paraense Emilio Goeldi (MPEG). The identification of the host plants was carried out in collaboration with botanical taxonomists and technicians from the MPEG, following APG IV (2016) and Tropicos (https://www.tropicos.org/nameSearch).

The identification of the Pucciniales specimens followed the observation of sori under a Leica EZ4 stereomicroscope to examine the lesions on the plant tissue and the presence of spores, and the preparation of semi-permanent slides of sori, spores and other microstructures in slightly heated drops of lactoglycerol (distilled water + lactic acid + glycerin) to be analyzed using Zeiss Axiolab optical microscopy (Neergaard et al. 2000; Aparecido and Passador 2009). Twenty-five spores randomly selected from each specimen were measured. Size variation was expressed by minimum and maximum values. Illustrations of the microstructures were made using an optical microscope attached to a digital camera. For the examination of the surface of fungal structures in scanning electron microscopy (SEM), the methodology of França and Sotão (2009) was adopted. Dry leaf material with rust fungi was hand cut with a razor blade into small pieces of approximately $4 \times 4 \mathrm{~mm}$. The samples were mounted onto aluminum stubs with adhesive carbon tape and coated with gold. The images were obtained in a Tescan Mira3 SEM and recorded in digital mode.

Specialized literature with descriptions of species and identification keys was referred to subsidize the identification and description of the new taxa (Cummins and Hiratsuka 2003; Hennen et al. 2005; Carvalho Jr and Sotão 2010). The notations for life cycle description followed Salazar-Yepes and Carvalho Jr (2010). The holotypes were deposited at the MG Herbarium and registered in MycoBank (www.mycobank. org). Author names follow the standards of Index Fungorum (www.indexfungorum.org).

\section{RESULTS}

Aecidium margaritariae Sotão \& Piovezan, sp. nov. (Figure 1) MycoBank no.: MB 838085

Type: Brazil. Amapá: Mazagão, Mazagão Novo, on Margaritaria nobilis L.f. (Phyllanthaceae), 27 July 1995, H.M.P. Sotão et al. 95-244, sori I (Holotype: MG 230298).

Diagnosis: Aecidium margaritariae can be distinguished from other Aecidium species occurring on Phyllanthaceae by the presence of peridial cells with smooth outer walls and warty inner walls, and globose, subglobose to slightly ellipsoid aeciospores with warty walls and smooth areas usually in the basal portion, measuring $27.5-37.5 \times 21.5-27.5 \mu \mathrm{m}$.

Spermogonia adaxial, subcuticular, gregarious, punctate, brown to black. Aecia abaxial, on irregular leaf spots, forming galls, grouped, cup-shaped, with white to pale yellow peridia; peridial cells oblong to ellipsoid, 30-40 × 15-17.5 $\mu \mathrm{m}$, with smooth outer wall and warty inner wall, $1 \mu \mathrm{m}$ thick, hyaline; aeciospores catenulate, $27.5-37.5 \times 21.5-27.5 \mu \mathrm{m}$, globose, subglobose to slightly ellipsoid, wall thin, $0.5-1 \mu \mathrm{m}$ thick, warty with smooth areas usually in the basal portion, hyaline. Uredinia and telia unknown. Life cycle (0/Icv,?,?).

Etymology: the epithet refers to the genus of the host plant, Margaritaria, on which the described rust was found.

\section{Known distribution: Brazil}

Uromyces amapaensis Sotáo \& Piovezan, sp. nov. (Figure 2) MycoBank no.: MB 838086

Type: Brazil. Amapá: Cutias, on Jatropha gossypiifolia L. (Euphorbiaceae), 05 December 2005, H.M.P. Sotão H200502, sori II, III (Holotype: MG 230259).

Diagnosis: Uromyces amapaensis is characterized by presenting paraphysate uredinia and telia whose paraphyses have thickened and rounded tips, and pedicellate and smooth teliospores, different from Uromyces cnidoscoli Henn. which has no paraphyses in uredinia and telia, and has minutely ornamented teliospores.

Spermogonia and aecia not seen. Uredinia scattered over the abaxial surface, orangish, subepidermal, pulverulent, grouped; paraphyses clavate, aseptate, $20-36 \times 5-13.5 \mu \mathrm{m}$, smooth-walled, thickened and rounded at the tip $(3-4 \mu \mathrm{m})$, light brown; urediniospores broadly globose, subglobose to ellipsoid, pedicellate, $20-30 \times 19-20 \mu \mathrm{m}$, wall hyaline to light brown, $2-3 \mu \mathrm{m}$ thick, moderately or densely echinulate, echinulations throughout the spore surface, but slightly irregular, germ pores not seen. Telia in uredinia, teliospores pedicellate, ellipsoid, $20-32 \times 16-20 \mu \mathrm{m}$, lateral wall $1.5-2$ $\mu \mathrm{m}$, thickened at the apex, 3-5 $\mu \mathrm{m}$, smooth. Life cycle (?/?) IIpe/III).

Etymology: The specific epithet refers to the Brazilian state of Amapá.

Known distribution: Brazil 
ACTA

AMAZONICA
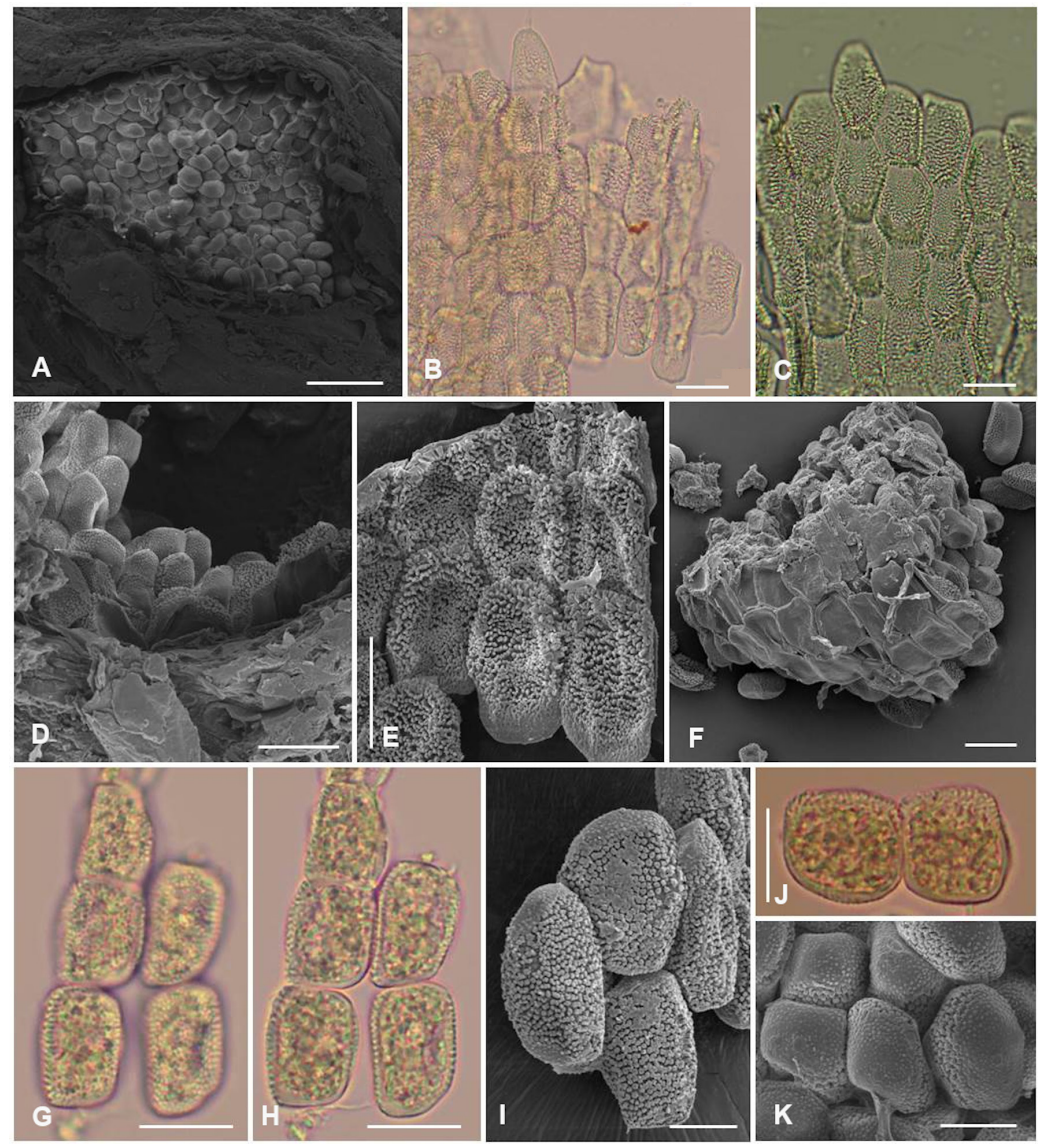

Figure 1. Aecidium margaritariae (MG 230298, holotype). A - Superficial view of an aecium (SEM); B-C - Peridial cells; D - Peridial cells on aecium (SEM); E- Inner wall of peridial cells (SEM); F - Outer wall of peridial cells (SEM); G-H - Aeciospores in superficial view (left) and medium focus (right); I - Aeciospores (SEM); J-K - Aeciospores with smooth areas in the basal portion. Scale bars: $\mathrm{A}=50 \mu \mathrm{m} ; \mathrm{B}-\mathrm{H}, \mathrm{J}=20 \mu \mathrm{m} ; \mathrm{I}, \mathrm{K}=10 \mu \mathrm{m}$. This figure is in color in the electronic version.

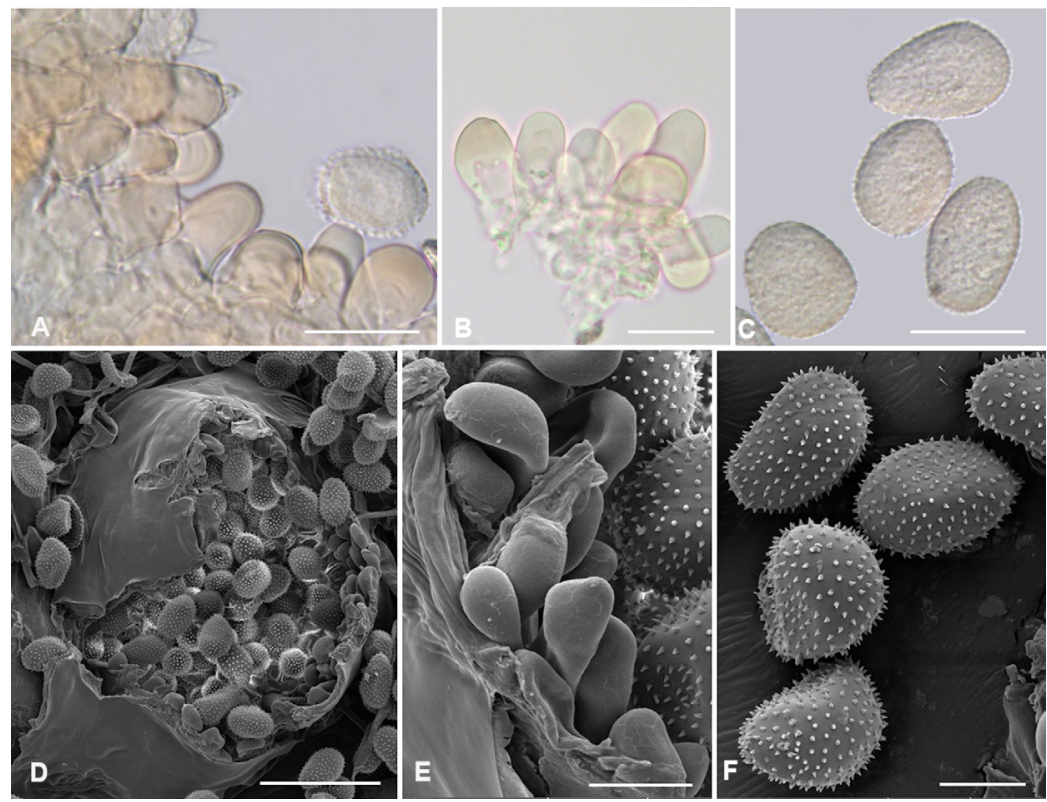

Figure 2. Uromyces amapaensis (MG 230259, holotype). A - Paraphyses, urediniospore and teliospores; B - Paraphyses and teliospores; C - Urediniospores in medium focus; D - Superficial view of uredinium with urediniospores, paraphyses and teliospores (SEM); E - Detail of paraphyses and teliospores (SEM); F - Urediniospores (SEM). Scale bars: $A=50 \mu \mathrm{m} ; B-D=20 \mu \mathrm{m} ; E-F=10 \mu \mathrm{m}$. This figure is in color in the electronic version. 


\section{DISCUSSION}

Aecidium margaritariae on $M$. nobilis is the second record of rust on this host genus. The first is $A$. entebbense Cummins, found on Margaritaria discoidea (Baill.) G.L. Webster (= Phyllanthus discoideus (Baill.) (Cummins 1945). Unlike $A$. margaritariae, in $A$. entebbense the peridial cells are smaller (13-19 × 18-25 $\mu \mathrm{m})$, oblong to polyhedral, with striate outer walls and warty inner walls, and the aeciospores are smaller $(13-18 \times 16-23 \mu \mathrm{m})$, with apically thickened $(3-8 \mu \mathrm{m})$ and uniformly warty walls (Cummins 1945).

Another five species of Aecidium are known to parasitize other plant genera of Phyllantaceae: Aecidium detritum (Phyllanthus sellowianus (Klotzsch) Müll. Arg.), A. fluggeae (Flueggea virosa (Roxb. ex Willd.) Royle, = F. microcarpa (Blume) Müll. Arg.), A. luzoniense (Phyllanthus sp.), A. phyllanthi (Phyllanthus sp.), A. phyllanthi-floribundi (Phyllanthus floribundus Müll. Arg.) and A. phyllanthinum (Phyllanthus reticulatus Poir.) (Hennings 1892, 1900; Sydow et al. 1907; Doidge 1927; Viennot-Bourgin 1954; Buriticá et al. 2014), with distinct characteristics from those of the new species presented here.

Other rust species registered on Phyllanthaceae have uredinia only, namely, Uromyces phyllanthi Henn., $U$. phyllanthi-longifolii Petch, U. phyllanthi-niruris M.S. Patil, and U. phyllanthi-reticulati Petch (Hennings 1896; Petch 1917, 1922; Patil 1991). Teleomorphic species include Coleosporium phyllanthinum Syd. (Sydow 1937), Masseeella capparis (Hobson bis ex Cooke) Dietel (Liberato et al. 2014), Masseeella narasimhanii Thirum. (Thirumalachar 1943), Phakopsora fenestrala (Arthur) Arthur (Arthur 1917), P. phyllanthi Dietel (Dietel 1910), P. phyllanthi-discoidei Vienn.-Bourg. (ViennotBourgin 1954), P. purdueae Buriticá \& J.F. Hennen, P. tijucae Buriticá \& J.F. Hennen, and P. ulei (Syd. \& P. Syd.) Buriticá \& J.F. Hennen (Buriticá 1999).

Uromyces amapaensis represents a new species of rust fungi occurring on Jatropha. Five species are known to affect these plants: Phakopsora arthuriana Buriticá \& J.F. Hennen, Uromyces agnatus Arthur, U. cnidoscoli, U. jatrophae Dietel. \& Holw. and U. oaxanacus Dietel \& Holw. (Monoson \& Prose 1983, Hennen et al. 2005). Uromyces amapaensis is easily differentiated from the other Uromyces species mentioned earlier by the presence of a few paraphyses with thickened tips and pedicellate and smooth teliospores.

Berndt (2002) recorded U. cnidoscoli on Jatropha sp. in Argentina. The Argentinean specimen presented transversely ellipsoidal, grossly warty, dark brown teliospores and pedicels whose apical parts dilated appreciably in aqueous medium. Before that, only the type had been reported from Brazilian collections (Goiás state), in which only teliospores had been observed, however, Berndt (2002) was able to report the presence of spermogonia, aecia and uredinia in the species. Hennings (1895) described U. cnidoscoli on Cnidoscolus vitifolius (Mill.) Pohl and commented that Aecidium cnidoscoli Henn. probably belonged to the life cycle of this species.

Phakopsora arthuriana differs from $U$. amapaensis by presenting subepidermal, non-erumpent telia with 6 to 12 layers of sessile spores, and numerous paraphyses (Hennen et al. 2005). The urediniospores of $U$. amapaensis are morphologically similar to those of $P$. arthuriana, but they are pedicellate. The paraphyses are similar in the two species, but in $P$. arthuriana they are numerous and have larger dimensions (20-50 × 9-12 $\mu \mathrm{m}$ vs. 20-36 × 5-13.5 $\mu \mathrm{m}$ in U. amapaensis) and the teliospores are smaller $(10-27 \times 7-13 \mu \mathrm{m})$ (Hennen et al. 2005).

Monoson and Prose (1983) listed 20 autoecious Uromyces species infecting Euphorbiaceae plants in the new world. They presented a key that differentiated them primarily based on the smooth or ornamented walls of the teliospores. Only Uromyces cisneroanus Speg. on Sapium sp. has a smooth wall like that of $U$. amapaensis, but it presents as distinctive characteristics teliospores with hyaline outer wall and dark inner wall and thickened apex $(5-18 \mu \mathrm{m})$, and urediniospores measuring $30-50 \times 14-24 \mu \mathrm{m}$.

Uromyces amapaensis also presents urediniospores with significant differences in relation to some Uredo species that parasitize Euphorbiaceae plants. Uredo alchorneae Henn. (Alchornea sp.) and Uredo paulistana Speg. (Acalypha sp.) do not have paraphyses and have slightly angular urediniospores which are smaller than those of $U$. amapaensis (Saccardo and Trotter 1912; Hennen et al. 2005). Uredo saviae Arthur \& J.R. Johnst. (Savia sp.) has angularly obovoid urediniospores, usually triangular (Arthur and Johnston 1918). Uredo valentula H.S. Jacks \& Holw. (Croton spp.) has spermogonia, aecia and uredinia in their life cycle, with urediniospores presenting thickened apical wall $(3-5.5 \mu \mathrm{m})$ and three slightly supraequatorial germ pores (Hennen et al. 2005). In turn, Uredo maceiensis Henn. (Maprounea sp.) presents uredinia with paraphyses thickened at the tip just like $U$. amapaensis, but in $U$. maceiensis the paraphyses are larger $(30-50 \times$ 15-16 $\mu \mathrm{m}$ vs. $20-36 \times 5-13.5 \mu \mathrm{m}$ in $U$. amapaensis), the urediniospores are usually ovoid, 4-6 $\mu \mathrm{m}$ thick at the apex, showing three equatorial germ pores (Hennen et al. 2005).

Until now, nine species and two varieties of rust fungi have been described on Euphorbiaceae in the Brazilian Amazon, occurring on Maprounea Aubl. (Aecidium maprouneae var. maprouneae Henn., Aecidium maprouneae var. noncrassatum J.F. Hennen \& Sotão, Chaconia maprouneae (Viégas) Y. Ono \& J.F. Hennen, and Uredo maceienses); Alchornea Sw. (Olivea capituliformis (Henn.) Arthur and U. alchorneae); and Jatropha L. (Phakopsora arthuriana, Uromyces cnidoscoli, and U. jatrophae) (Hennen and Sotão 1997; Hennen et al. 2005; Carvalho et al. 2018). 


\section{CONCLUSIONS}

This study adds two new species of rust fungi to the Brazilian and Amazonian mycobiota. Aecidium margaritariae is the second species of rust fungus found on Margaritaria nobilis, while Uromyces amapaensis is the fifth species of rust fungi described on Jatropha gossypiifolia. Our finds increase the known Brazilian mycobiota, highlighting the need to explore new areas in the Amazon region, where fungal diversity remains underestimated.

\section{ACKNOWLEDGMENTS}

PMPO thanks the Conselho Nacional de Desenvolvimento Científico e Tecnológico (CNPq) for the scholarship received; JSM thanks the Programa de Capacitação Institucional (Museu Paraense Emílio Goeldi/MCTIC) (Process 300646/2019-4); all authors thank the Programa de Pesquisa em Biodiversidade (PPBio) Amazônia Oriental, for financial and logistic support, the Instituto Chico Mendes de Conservação da Biodiversidade (ICMBio) for logistic support, and Dr. Ricardo Secco and Luiz Carlos Lobato for the identification of the host plants.

\section{REFERENCES}

Aime, C.M.; Matheny, P.B.; Henk, D.A.; Frieders, E.M.; Nilsson, R.H.; Piepenbring, M.; et al. 2006. An overview of the higher level classification of Pucciniomycotina based on combined analyses of nuclear large and small subunit rDNA sequences. Mycologia, 98: 896-905.

Aime, C.M.; Bell, C.D.; Wilson, A.W. 2018. Deconstructing the evolutionary complexity between rust fungi (Pucciniales) and their plant hosts. Studies in Mycology, 89: 143-152.

Aparecido, C.C.; Passador, M.M. 2009. Metodologia para estudos biológicos em Uredinales. Infobibos - Informaçôes Tecnológicas. (http://www.infobibos.com/Artigos/2009_2/Uredinales/index. htm). Accessed on 15 Oct 2020.

Aparecido, C.C.; Passador, M.M. 2014. Estudos biológicos de espécies de Puccinia utilizando "germinatélios". Bioscience Journal 30: 440-447.

APG IV. 2016. An update of the Angiosperm Phylogeny Group classification for the orders and families of flowering plants: APG IV. Botanical Journal of the Linnean Society, 181: 1-20. doi.org/10.1111/boj.12385

Arthur, J.C. 1917. Relationship of the genus Kuehneola. Bulletin of the Torrey Botanical Club, 44: 501-511.

Arthur, J.C.; Johnston, J.R. 1918. Uredinales of Cuba. Memoirs of the Torrey Botanical Club, 17: 97-175.

Berndt, R. 2002. Additions to the rust fungi of Argentina. Mycologia, 94: 523-534.

Buriticá, P. 1999. La familia Phakopsoraceae en el Neotrópico III, Géneros: Batistopsora y Phakopsora. Revista de la Academia Colombiana de Ciencias Exactas, Físicas y Naturales, 23: 271-305.

Buriticá, P.; Salazar-Yepes, M.; Pardo-Cardona, V.M. 2014. Pucciniales (Fungi), Royas de Colombia. Revista Facultad Nacional de Agronomía Medellin, 67 (suppl. 1): 1-93.
Cardoso, D.; Särkinen, T.; Alexander, S.; Amorim, A.M.; Bittrich, V.; Celis, M.; et al. 2017. Amazon plant diversity revealed by a taxonomically verified species list. PNAS, 114: 10695-10700.

Carmo, L.T.; Sotão, H.M.P.; Brito, F.M.; Moura, M.F.; Oliveira, J.R. 2016. Riqueza de fungos causadores de ferrugens em plantas hospedeiras da Regiāo Metropolitana de Belém, PA, Brasil. Hoehnea, 43: 557-573.

Carvalho-Jr., A.A.; Sotão, H.M.P. 2010. Pucciniales. In: Forzza, R.C. et al. (Orgs.). Catálogo de plantas e fungos do Brasil. 1. ed. Andrea Jakobsson Estúdio: Instituto de Pesquisas Jardim Botânico do Rio de Janeiro, Rio de Janeiro, p.210-. (http://www.jbrj.gov.br). Accessed on 07 Feb 2021.

Carvalho, A.C.; Sotão, H.M.P.; França, I.F. 2018. Fungos causadores de ferrugens (Pucciniales) em plantas da Reserva Florestal Adolpho Ducke, Amazônia Central, Brasil. Rodriguésia, 69: 663-672.

Cummins, G.B. 1945. Descriptions of tropical rusts. VII. Bulletin of the Torrey Botanical Club, 72: 205-222.

Cummins, G.B.; Hiratsuka, Y. 2003. Illustrated Genera of Rust Fungi. 3rd ed. The American Phytopathological Society Press, St. Paul., 225p.

Dietel, P. 1910. Zwei neue Arten der Gattung Phakopsora. Annales Mycologici, 8: 469-469.

Doidge, E.M. 1927. A preliminary study of the South African rust fungi. Bothalia, 2: 1-228.

Flora do Brasil 2020. 2021. Jardim Botânico do Rio de Janeiro. (http:// floradobrasil.jbrj.gov.br/). Accessed on 15 Feb 2021.

França, I.F.; Sotão, H.M.P. 2009. Novos registros de ferrugens (Uredinales) sobre Fabaceae para o Brasil. Acta Botanica Brasilica, 23: 860-863.

França, I.F.; Sotão, H.M.P.; Costa-Neto, S.V. 2010. Fungos causadores de ferrugens (Uredinales) da Reserva Biológica do Lago Piratuba, Amapá, Brasil. Rodriguésia, 61: 211-221.

Furtado, R.G.; Sotão, H.M.P.; Monteiro, J.S.; Brito, F.M. 2018. Primeiro registro para o Brasil de Maravalia bolivarensis Y. Ono (Pucciniales) parasitando Manilkara sp. (Sapotaceae). Hoehnea, 45: 129-133.

Hennen, J.F.; Figueiredo, M.B.; Carvalho Jr., A.A.; Hennen, P.G. 2005. Catalogue of the Species of Plant Rust Fungi (Uredinales) of Brazil. Jardim Botânico do Rio de Janeiro, Rio de Janeiro, 490p. (http://aplicacoes.jbrj.gov.br/publica/livros_pdf/catalogue.pdf). Accessed on 09 Jun 2021.

Hennen, J.F.; Sotão, H.M.P. 1997. Aecidium maprouneae var. noncrassatum (Uredinales) sobre Maprouneae sp., novo táxon do estado do Amapá, Brasil. Fitopatologia Brasileira, 22: 444-447.

Hennings, P. 1892. Fungi novo-guineenses. Botanische Jahrbücher für Systematik Pflanzengeschichte und Pflanzengeographie, 15(Beibl. 33): 4-8.

Hennings, P. 1895. Fungi blumenavienses, a cl. Alfr.Moller lecti. Hedwigia, 34: 335-558.

Hennings, P. 1896. Beiträge zur Pilzflora Südamerikas I. Uredineae. Hedwigia, 35: 202-262.

Hennings, P. 1900. Fungi monsunenses. Monsunia, 1: 1-38. 
Liberato, J.R.; McTaggart, A.R.; Shivas, R.G. 2014. First report of Masseeëlla capparis in Australia. Australasian Plant Disease Notes, 9: 121. doi.org/10.1007/s13314-013-0121-y

Monoson, H.L.; Prose, S.E. 1983. Autoecious Uromyces that infect New-World Euphorbiaceae. Mycologia, 75: 436-450.

Neergaard, E.; Lyshede, O.B.; Gahoonia, T.S.; Care, D.; Hooker, J.E. 2000. Anatomy and histology of roots and root-soil boundary. In: Smit, A.L.; Bengough, A.G.; Engels, C.; Noordwijk, M.; Pellerin, S.; Geijn, S.C. (Eds.). Root Methods: A Handbook. Springer-Verlag, Berlin, p.33-73.

Patil, M.S. 1991. Rust fungi from Maharashtra - IV. Indian Phytopathology, 44: 433-439.

Petch, T. 1917. Additions to Ceylon fungi. Annals of the Royal Botanic Gardens Peradeniya, 6: 195-256.

Petch, T. 1922. Additions to Ceylon fungi II. Annals of the Royal Botanic Gardens Peradeniya, 7: 279-322.

Saccardo, P.A.; Trotter, A. 1912. Sylloge Fungorum, 21: 1-928.
Salazar-Yepes, M.A.; Carvalho, A.A. 2010. Ferrugens: Diversidade de Uredinales do Parque Nacional do Itatiaia, Brasil. Ed. Technical Books, Rio de Janeiro, 201p.

Sydow, H. 1937. Novae fungorum species. XXV. Annales Mycologici, 35: 244-286.

Sydow, H.; Sydow, P.; Butler, E.J. 1907. Fungi Indiae orientalis pars II. Annales Mycologici, 5: 485-515.

Thirumalachar, M.J. 1943. Masseeella narasimhanii, a new species of rust on Flueggea leucopyrus Willd. Proceedings of the Indian Academy of Sciences Section B, 18: 36-40.

Viennot-Bourgin, G. 1954. Urédinales d'Afrique. 4. Urédinales de Côte d'Ivoire. 3. Bulletin de la Société Mycologique de France, 70: 410-419.

RECEIVED: $19 / 02 / 2021$

ACCEPTED: 30/05/2021

ASSOCIATE EDITOR: Nelson Menolli Junior 